\title{
THE SA CONSTITUTION AND RELIGIOUS FREEDOM: PERVERTER OR PRESERVER OF RELIGION'S CONTRIBUTION TO THE PUBLIC DEBATE ON MORALITY?
}

\author{
Pieter Fourie \\ Uniting Reformed Church in Southern Africa \& Research Associate \\ Faculty of Theology \\ University of Stellenbosch
}

\begin{abstract}
The South African Constitution should be interpreted differently from the North American one, or else religion will forfeit any role as a partner in the public debate on morality. The history of interpretation and implementation of the North American constitution serves as an example of a secular scenario that we as South Africans should try and avoid. American jurisprudence on the First Amendment, by which religious freedom in that country is guaranteed, led to a complete separation between religion and the state as representative of the public sphere. This is the result of so-called "secular individualism". The text of the South-African Constitution allows for an interpretation whereby the rights of groups, also religious, contrary to those of individuals only, are recognised. That allows better for the diversity of a pluralistic democracy as in South Africa. However, tolerance and cultural openness, as active values, are needed to prevent the formation of a theocratic dictatorship, like we had under the previous regime in South Africa. Seen from this perspective, the Constitution is not a perverter but a preserver of religion's right to partake in the public debate on morality.
\end{abstract}

\section{Introduction}

Popular interpretation of the SA Constitution regards the Constitution as secular. Therefore, as far as public government is concerned, religion is banned to the private sphere of life. The public square is naked and void of moral rule. Within the framework of this paper, it should thus be stated: The SA Constitution is a perverter of religion's contribution to the public debate on morality.

A striking example that illustrates this popular (mis)understanding manifested itself in my own life when a well-known church newspaper had an interview with me on a study about the position of ministers and labour legislation. I wrote down a few key sentences that the reporter used to write the article. My notes clearly stated that the state in South Africa is not a secular one (although being neutral towards specific religions). The reporter still wrote the following (somewhat illogical) sentence: "Fourie indicated that, regarding religious freedom in South Africa, the state is secular, but it can still remain neutral towards religions."

The incident rather aptly illustrates my point: People are so fixated on the perception that the state is secular, that even a good reporter changed the notes she had received from the original author to what she must have perceived to be the correct statement. She clearly thought she was correcting a slip on my side. 
My thesis is: The South African Constitution should be interpreted differently from the North American one, or else religion will forfeit any role as a partner in the public debate on morality. The history of interpretation and implementation of the North American constitution serves as an excellent example of a secular scenario that we as South Africans should try and avoid.

\section{The so-called First Amendment in the USA}

Within the North American context, the so-called "First Amendment" forms a cornerstone of the American constitution. It reads: "Congress shall make no law respecting an establishment of religion or prohibiting the free exercise thereof." ${ }^{\text {An }}$ expression that has become almost idiomatic in this respect talks about the "wall of separation" between church and state. ${ }^{2}$ With this amendment, the separation between state and church within the Western history of Christianity had been established for the first time (Koshy 1992:28). The clause is also called the "Establishment Clause" (cf Justice HL Black in Engel vs Vitale 1962).

Jay Dolan says when people think about the American Revolution, they automatically think of the political revolution that transformed that country's colonies into the one new nation of the United States. There is, however, a second revolution: the way in which people think about God, religion and the relationship with the state (1995:17).

Dolan points to the fact that a combination of Pietism, which got under way during the so-called "Great Awakening", and the rationalists of the mid-eighteenth century created the climate in which the First Amendment, and thus a separation of church and state, could get off the ground.

The binding principle between the two movements was the emphasis they both put on the individual's freedom of choice - also the freedom to make religious choices that were not determined by the authority of any established religion. The rationalists provided the theoretical framework, the Pietists the passion, "the moral imperative, the fire in the belly that was needed in order to transform political theory into revolutionary doctrine" (1995:25).

Thomas Jefferson and James Madison, in their campaign for religious freedom, were successful in as far as they, as rationalists, provided the theory and intellectual background that finally convinced people to support the idea of religious freedom: "Pietists provided the enthusiasm, the moral imperative, that was needed to move people to support the ideas of Jefferson and Madison" (Dolan 1995:28).

\section{A hermeneutic history of the concept religious freedom in the USA}

A definition of religion in the USA became particularly important during the Vietnamese war, when people tried to get exemption from military service on the basis of their religious convictions.

1. Note the important two elements of this clause: establishment and free exercise. When we discuss the South African Constitution, this distinction will be important.

2. Apparently this expression dates back to Thomas Jefferson himself, in an address to the Danbury Baptist Association, when he told the Baptists: "Believing with you that religion is a matter that lies solely between man and his God; that he owes account to none other for his faith or his worship... I contemplate with sovereign reverence that act of the whole American people which declared that their legislature should 'make no law respecting an establishment of religion or prohibiting the free exercise thereof' thus building a wall of separation between church and State" (Washington Evening Star, June 27, 1962). 
In 1890 the American High Court defined religion as follows: "The term religion has reference to one's view of his relations to his Creator, and to the obligations they impose of reverence for his being and character, and of obedience to his will. It is often confounded with the cultus or form of worship of a particular sect, but is distinguishable from the latter ... With man's relations to his Maker and the obligation he may think they impose, and the manner in which an expression shall be made by him of his belief on those subjects, no interference can be permitted, provided always the laws of society, designed to secure its peace and prosperity, and the morals of its people are not interfered with" (quoted in Abraham 1995:167).

Sixty-one years later, a further ruling still held that religion involved "an individual belief in a relation to a Supreme Being involving duties superior to those arising from any human relation" (cf Abraham 1995:173). But a mere fourteen years later, however, the metaphysical dimension was dropped as part of the religious definition.

This happened when three military conscripts in 1965, despite no apparent traditional belief in a transcendent and metaphysical being, pleaded exemption from military service on religious grounds. They stated that to them their passion against any form of war and in favour of life had religious dimensions. The High Court therefore decided that in future the definition of religion should be extended to include "any sincere and meaningful belief parallel to a belief in God" (cf Abraham 1995:175). ${ }^{3}$

McConnel indicates that the First Amendment was actually the product of minority religions, from a time when every religion in the USA used to be a minority religion. The original meaning of this religious clause was not to be an instrument of secularisation or a weapon for non-religious or anti-religious groups. "The Religion Clauses were intended to guarantee the rights of those whose religious practices seemed to the majority a little odd" (Eastland 1993:499).

This view is also expressed in Justice Black's opinion in Engel vs. Vitale (1962): "The First Amendment was added to the Constitution to stand as a guarantee that neither the power nor the prestige of the Federal Government would be used to control, support or influence the kinds of prayer the American people can say - that the people's religions must not be subjected to the pressures of government for change each time a new political administration is elected to office" (as quoted in Eastland 1993:129).

Certainly non-believers also had to be protected against religious dominance. However, "... we must not think that was the exclusive, or even the primary, focus of the religiousfreedom advocates of the founding period" (McConnell 1992:499). McConnell warns against the abuse of this clause in a way that boils down to a "... demand for freedom from religion, not freedom of religion" (1992:507). The ideal of this Amendment is to create and promote religious diversity, and not "dull and conformist secularism" (1992:507). The religious clause is the champion of outsiders and minorities, and enables them to also act like outsiders and minorities. "It behooves us to recognize that protecting religious minorities will sometimes mean protecting and perpetuating practices we deem morally repugnant" (McConnell 1992:505).

On this point McConnell has a huge problem with the way in which the First Amendment has been interpreted in USA legal history, as manifested in a number of court

3. John Witte holds the view that a definition by which every conviction that a person holds dear could be classified as a religious conviction and qualify for constitutional and judicial protection, defeats the purpose of having a religious freedom clause at all. In the end, the issue of religious rights becomes so wide and vague that it loses all meaning (cf Witte 1996:xxv). 
decisions in that country. Perhaps the most outstanding of these decisions is the ruling about prayer in public schools.

Since their inception in the nineteenth century, public schools in most parts of the USA had sponsored prayers and other devotional exercises. In 1962, in Engel vs. Vitale, the Court held that under the First Amendment a state might not sponsor prayers in its schools. No other ruling in this area of constitutional law has provoked as much sustained public controversy.

In the above case, the New York State Board of Regents composed and recommended for daily use in New York public schools a brief, non-denominational prayer: "Almighty God, we acknowledge our dependence upon Thee, and we beg Thy blessings upon us, our parents, our teachers and our Country". The prayer was justified as a part of a child's moral and spiritual training, and participation was voluntary. The New York courts were satisfied that the prayer was not an establishment of religion as long as the schools did not compel any student to join in the prayer over his or his parents' objection. The Supreme Court, however, disagreed. What offended the First Amendment was the fact that government had engaged in a religious activity by writing a prayer.

In its response to the verdict, the Wall Street Journal (27.06.62) wrote: "Shall we uproot all teaching of the Bible with its magnificent poetry and philosophy? Out the window with everything from Dante to Donne, from Milton to Dickens? Or how can public school teachers teach about Bach or Michelangelo, when the context is inescapably religious? Asked the Washington based Wall Street Journal (27.06.62). "Would Mr Jefferson be as bewitched and bewildered as many of us today by the view which the Supreme Court takes of Mr Jefferson's wall?" (27.06.62).

The case Abington vs. Schemp (1963), lead to a prohibition on saying the Lord's Prayer and all Scripture readings in public schools. The dissenting judge, Justice Stewart, in his minority opinion said: "What our Constitution indispensably protects is the freedom of each of us, Jew or Agnostic, Christian or Atheist, Buddhist or Free-thinker, to believe or disbelieve, to worship or not to worship, to pray or to keep silent, according to his own consciousness uncoerced and unrestrained by government" (Eastland 1993:166). He asks whether school boards could not be trusted to do justice to this principle in practice.

Afterwards the Evening Star wrote: "To us, this (what Justice Stewart said) is quite different from saying that the Constitution forbids one child, who may wish to do so, to recite the Lord's Prayer in a public school merely because some other child, who does not want to pray and who is not required to pray, objects" (18.06.1963).

The fear of compromised state neutrality on religion and the emphasis on individualism in the above-mentioned two cases are all the more significant when one considers the opinion expressed only a decade earlier in Zorach vs. Clauson (1952). In this the constitutionality of a so-called "released time" program was judged upon. In New York religious instruction was provided off the public school premises for school students who wanted to attend these classes during school time and had the permission of their parents. They were allowed to attend the classes, on the condition that they supplied a report from the religious leader that they had in fact attended the instruction. "We are a religious people whose institutions presuppose a Supreme Being", declared Justice Douglas. "When the state encourages religious instruction or cooperates with religious authorities by adjusting the schedule of public events to sectarian needs, it follows the best of our traditions. For it then respects the religious nature of our people and accommodates the public service to their spiritual needs" (Eastland 1993: 108 - cursive mine). According to Gedicks, this was one of the last cases that openly relied on religious communitarian discourse, contrary to a 
secular individualistic one, to justify a decision (see the definitions below) (Gedicks 1995:62). ${ }^{4}$

Judging from the hermeneutic history that developed around the First Amendment/ Establishment Clause, the interpretation of this Clause deviated more and more from its original aim of preserving and promoting religious pluralism of (minority) groups into advancing a different aim, namely that of individualistic secularism.

\section{Two frameworks of interpretation}

Gedicks is of the opinion that the preceding court rulings (and also other rulings on the limitation of religious freedom) reflect a gradual shift in the particular philosophical and hermeneutical framework from which religion is viewed (1995:11). I find his analysis of two frameworks quite useful for the debate.

The first of these frameworks, and one that was still operative in the 1952 case of Zorach vs. Clauson 1952 (see above), Gedicks calls "religious communitarian discourse" (1995:11). This discourse presumes a society in which church and state are institutionally separated, but not politically or culturally. Religious communitarianism understands religion to be the principal source of certain values and practises that lie at the base of civilised society. This discourse acknowledges that tradition and authority are important building blocks for society, and that reason and individualism are not necessarily the primary cornerstones thereof. ${ }^{5}$

The second framework is called "secular individualism" (Gedicks 1995:13). Gedicks believes this framework to be the philosophical foundation on which the whole house of American jurisprudence on religious freedom and the First Amendment since the 1960's was built.

Typical of this framework is that knowledge is discovered by the right application of critical reason, and never by a simple appeal to religious authority or tradition. Religion, in fact, is considered as an irrational and regressive antisocial force that must be confined strictly to private life, in order to avoid social division, violence and anarchy. Religious belief is a choice in private life that is insulated from government influence and control, while public life is the realm of the objective, secular discourse, protected from the irrationality and subjectivity of faith. In contrast to religious communitarian discourse, it is never acceptable for government to defend its actions with a religious justification. On the contrary, this is precisely the evil to be avoided. Any so-called public religion is only acceptable to secular individualism to the extent that it falls within broader secular categories of public life (cf Gedicks 1995:12).

This foundational framework explains the type of jurisprudence that leads to a situation in the USA:

4. The establishment clause doctrine of the Court was expanded further with the introduction of what became known as the Lemon test. Under this test (Lemon vs Kurtzman, 1971) government actions are judged against the following three yardsticks: Do they advance religion, do they lack a secular purpose, or do they threaten to entangle government with religion. Actions failing this test are condemned. Or, in terms of the refashioning of this test given by Justice O'Conner in two opinions handed down only a year apart (Lynch v Donelly 1984 and Wallace vs Jaffree 1985), government unacceptably departs from the political neutrality imposed by the establishment clause whenever it endorses or disapproves a person's religious beliefs or practices.

Against the above test, McConnell's biggest complaint is: "By forbidding all government action that has the effect of 'advancing' religion - even by preserving its free exercise - the Lemon test fosters secularism, not religious pluralism" (Eastland 1993:502).

5. I have adapted Gedicks' description slightly. 
- where religious institutions are being prevented from running community welfare programmes on the same footing as secular and private organisations, simply because they are not allowed state funding;

- where legal exemptions for the free exercise of religion may only be given on secular grounds; ${ }^{6}$ and

- where a hyper-sensitivity to coercion with respect to religious practice reigns, as revealed in the cases on Scripture reading and prayer in public schools.

"Why, Americans can ask, is the Court's sensitivity to coercion so high with respect to religious practices that threaten secular programs, and so low with respect to secular practices that threaten religious belief and practice?" (Gedicks 1995:120). Very critically, with positive reference to Stephen Carter, Gedicks says: "Public school prayer is no more coercive than an educational curriculum that forces a religious conservative child to learn about evolution or condoms. ... Indeed, why are the mere feelings of atheists, agnostics, and other dissenters entitled to constitutional protection ... while essential practices of religious groups are left to the uncertain political process?" (1995:120).

Clearly, Gedicks' problem with the American jurisprudence on religious freedom is that the interpretation of that freedom boils down to a limitation on religions as such and their possible contribution to the public sphere and as a result an advancement of a secular agenda (thus: not freedom of religion, but freedom from religion).

\section{Religious freedom and the RSA}

The concept "religious freedom" has a long history. In a theocratic state, naturally only the official state religion is tolerated. From the beginning, however, the situation with Christianity was different in as far as it found itself in the hostile environment of the classical Greek and Roman civilisations. Since this religion's early days, tension reigned between the adherents of Christianity and the political leaders.

However, within Christianity a new form of theocracy gradually reared its head when the pope, as ecclesiastical ruler, claimed more and more political powers for himself. This reached a climax when Boniface VIII, in his Unam sanctam of 1302, declared it necessary that every human being subjects him- or herself to the Pope's authority.

Tierney writes that “... it was not until the liberal revolutions of the nineteenth century that freedom of religion became widely established in the constitutions of Western states, and not until the twentieth century that the major Christian churches proclaimed religious

6. Perhaps one of the best illustrations of how a secular motive is given to achieve a clearly religious communitarian result, is the McGowan vs Maryland 1961 case about Sunday closing laws. The court first determined that, appearances notwithstanding, the purpose for the closing laws was secular rather than religious, arguing that despite restrictions on business and commercial activities, the sports, entertainment and other secular activities permitted by the laws "seem clearly to be fashioned for the purpose of providing a Sunday atmosphere of recreation, cheerfulness, repose and enjoyment ... one of relaxation rather than one of religion".

Having identified a secular purpose for requiring most businesses to close one day a week, the Court then concluded that Sunday was the day that most people would choose on their own, because that was the day people of all religions, or without religion, regard as a time for family activity, visiting friends and relatives, sleeping late and active entertainment and the like. So, by showing that Sunday closing laws had a secular purpose, and that the designation of Sunday as the secular day of rest was merely the public effect of private choice, it defended this remnant of a de facto Protestant establishment, which could easily have been done by religious communitarian discourse. 
rights as an essential feature of the Christian faith itself" (1996:43). To many, this freedom has become the most fundamental of all human rights. ${ }^{7}$

In South Africa, however, things were different. In his Ontluisterde Wêreld, Durand indicates how in South Africa, under the influence of Article 36 of the Belgic Confession, the ideal of a theocratic state reigned much longer. It was part of the Afrikaner Nationalist tradition until the final draft of the new Constitution (Durand 2002:52). Does anyone remember the heated debates as to whether the name of God should be included in the Constitution? Now the ideal of a theocratic state plays second fiddle to many other needs South Africans deem urgent.

In South Africa religious freedom as a constitutional right is a new concept. With the present SA Constitution, religious freedom itself is explicitly guaranteed in South Africa for the first time. Before the dawn of democracy, the dominance of Christianity amongst the religions was widely regarded as the norm. Saayman (with reference to Lubbe) says the situation in South Africa pre-democracy should rather be described as one of religious tolerance than one of religious freedom (1993:42). With the 1996 Constitution, that has changed dramatically.

Section 15(1) in the Bill of Rights of our Constitution reads: "Everyone has the right to freedom of conscience, religion, thought, belief and opinion."

That should be read together with Section 31 of the Constitution:

Cultural, religious and linguistic communities:

(1) Persons belonging to a cultural, religious or linguistic community may not be denied the right, with other members of that community -

(a) to enjoy their culture, practise their religion and use their language; and

(b) to form, join and maintain cultural, religious and linguistic associations and other organs of civil society.

(2) The rights in subsection (1) may not be exercised in a manner inconsistent with any provision of the Bill of Rights.

Smith states that the mere fact that religious and conscientious freedom are grouped together in our constitution, reveals something about the way in which we should understand the meaning of religion. "The drafters meant to protect traditional religious systems via freedom of religion and to protect some residual set of ethical belief systems through the freedom of conscience" (Smith 1998:19-1). Because conscience, religion, thought, belief and opinion are grouped together, there is no need for a separate definition of religion in the RSA (cf Ackermann 2001:3).

Despite this lack of a definition, Smith still argues that there should nevertheless be a limit to what could pass as religion, even amidst the growing diversity of religions. Despite an "objective standard" for what passes as religious belief, he believes there should still be

7. Eg. FI Gamwell, whose starting point is that “... religious freedom coherently means nothing other than a free political discourse" (1995:10). The "freedom" of religious freedom resembles the equal participation in the political discourse guaranteed under democracy to all citizens. Religious freedom is the expression par excellence of the so-called "democratic way". "There is no religious conviction whose teaching requires the state's guarantee; on the contrary, it is the complete freedom of the public debate or the 'democratic way' that is to be secured" (Gamwell 1995:131) - and Gamwell hereby includes the secularised conviction not to have any conviction.

Albie Sachs too expressed himself about the importance of religious freedom: "(It) is one of the most important constitutional questions facing any country.... In some respects it touches on what might be the most fundamental human right of all, certainly the most intimate and personal, the right to conscience" (Sachs 1990:43). 
something like a "family resemblance" among the various religious systems - almost like the word "game" calls forward a whole host of activities, without necessarily one definable trait common to all games (Smith 1998: 19-2, footnote 1). This is clearly a rejection of the American definition that includes "any sincere and meaningful belief parallel to a belief in God" (see the above).

As far as the concept religious freedom is concerned, a leading Canadian court definition has become a general definition standard (and was also repeated in the first religious freedom case to be heard in South Africa - see below). It is the right “... to entertain such religious beliefs as a person chooses, the right to declare religious beliefs openly and without fear of hindrance or reprisal, and the right to manifest belief by worship and practice or by teaching and dissemination" ( $R v$ Big M Drug Mart Ltd, quoted in Lawrence et al, 1999, par 92).

\section{The USA and us: the difference}

The important point for this paper is: There is no reason for us in South Africa to follow the American hermeneutic route when we start implementing and applying the concept of religious freedom here, despite the many similarities that are starting to develop between us and our American counterparts, particularly as far as our catching up with the secularisation of that community is concerned.

An important difference in our Constitution is that we have do not have an establishment clause as part of the religious freedom clause (Section 15). Certainly, in the First Amendment establishment and the right to free exercise are aspects of the same issue, namely freedom of religion. However, the absence of an establishment clause in our Constitution gives a completely different perspective to the interpretation of our Constitution to that of our American counterparts.

The absence of an establishment clause per se still does not tell us anything about the clause's meaning and purpose. However, the addition of Section 15(2) “... makes it clear that the drafters of the Constitution wanted to distance themselves from some Establishment Ruling (such as those that forbid school prayer)" (Smith 1998:19-18). They downplayed the sharp distinction between church and state in the USA, created by the history of interpretation of the establishment clause (cf Smith 1998:19-10). ${ }^{8}$

Section 15(2) of the Constitution reads:

"Religious observances may be conducted at state or state-aided institutions, provided that -

(a) those observances follow rules made by the appropriate public authorities;

(b) they are conducted on an equitable basis; and

(c) attendance at them is free and voluntary.

The free exercise of religion in South African schools is therefore not unconstitutional. However, the implementation thereof should be critically tested by questioning in how far these occasions are being organised in such a way that they are truly equitable and voluntary. "While it is clear that in South Africa school prayer per se will not be unconstitutional, it will be possible to challenge particular devotional arrangements on the basis that they are not voluntary or equitable" (Smith 1998:19-10).

8. Even before the South African Constitution was finalised, Albie Sachs had already written: "The general principle of separation of church and state could be followed. Yet it need not be absolute." He mentions a couple of examples: "It could permit non-denominational places of prayer at state institutions, including in the buildings of Parliament itself. It could adopt Nkosi Sikelele as the national anthem" (1990:45). 
The matter of $S$ vs. Lawrence; $S$ vs. Negal; $S$ vs. Solberg 1997 was the first on the freedom of religion to be heard by our Constitutional Court. The Court was asked to find that certain provisions of the Liquor Act 27 of 1989 were unconstitutional in terms of the freedom of religion provision of the (then) interim Constitution. One of the appellants sold wine at a Seven Eleven store in contravention of the provisions of that Act, which stipulated that Sunday is a "closed day" on which no wine may be sold.

The judges were very divided on the issue. Five of them agreed that indeed those provisions were an infringement of religious freedom. Four of them said no. And of those who saw an infringement, some nevertheless held that the infringement was justified in terms of the Limitation Clause of Section 36 (33 in the Interim Constitution). The appellants therefore lost their case. It was said that had they attacked the Liquor Act on the basis that it constituted unfair discrimination in the religious context, in other words that the state was giving undue preference to one particular religion, they might have been successful. But then they might have well raised the issue under the Equality Clause (Section 9) of the Constitution - a route that they had not taken.

The important point for us, however, is the warning the judges in this case issued: Our Constitution should not be read with the typical USA principle of non-establishment in mind.

Justice Chaskalson said: "It is clear from the United States decisions that although there is an area in which the 'establishment' clause and the 'free exercise clause' overlap, the two clauses have different concerns. In developing our own jurisprudence, we should be careful not to blur this distinction."

"The primary purpose of the 'establishment clause' in the US Constitution is to prevent the advancement or inhibition of religion by the state. The primary purpose of the 'free exercise' clause is to permit adherents of different faiths to pursue their religious beliefs without being impeded from doing so by state coercion. Our Constitution deals with issues of religion differently to the US Constitution. It does so under the equality provisions of Section 8 (now 9- PJAF), the freedom of religion, belief and opinion provisions of Section 14 (now 15), and the education provisions of section 32 (now 29(3))" (Lawrence et al 1996, par 99-100). ${ }^{9}$

Different from the USA, advancing religion per se is not so much a constitutional prohibition. The Judge said: "Section 14 (now 15) does not include an 'establishment clause' and in my view we ought not to read into its provisions principles pertaining to the advancement or inhibition of religion by the state. To do so would have far reaching implications beyond the apparent scope and purpose of Section 14. If such obligations on the part of the state are to be read into Section 14 does this mean that Christmas Day and Easter Friday can no longer be public holidays, that 'Family Day' is suspect because it falls on Easter Monday, that the SABC as public broadcaster cannot broadcast church services (as it does regularly on Sunday mornings, though it does not regularly broadcast Muslim services on Fridays or Jewish services on Saturdays or Hindu services on any particular day of the week), that its daily religious programmes must be cancelled, and that state subsidies to denominational schools are prohibited? These examples can be multiplied" (Lawrence et al 1996, par 99-100).

What is clear from the South African Constitution is that no religion should be favoured above another. That would be a serious mistake, and the typical mistake of a theocratic era. But it is also not expected of the state to be secular.

9. See also below Section 31 about group rights. 
Surely, the state should be religiously neutral. That, however, does not mean that the state is not permitted to establish favourable conditions by which religion could be advanced (cf Ackermann 2001:6). The Constitution is only "secular" to the extent that it accords equal respect and protection to non-believers and believers alike and to the different religious denominations, but it does not erect a wall of separation between church and state (Ackermann 2001:2). "South Africa is rather a religion-neutral state whose constitutional provisions on the right to religious freedom sustain religion without preferring any particular faith or denomination" (Du Plessis 2001:10).

Differently said: The state itself is not religious. However, it favours religion(s) to such an extent that it guarantees the free expression thereof as a specific constitutional right. In the light of Section 7.2 of the Constitution (which promises that the state will respect, protect, promote and fulfil the rights in the Bill of Rights), the state is obligated to respect, protect and promote religious freedom and its application. In practice, this obligation has two aspects, negative and positive. Part of "promoting and respecting" certainly implies the non-coercion of non-religious people (the negative aspect: "Do not coerce non-religious people"). However, promoting and respecting also imply what should happen (the positive aspect).

An illustration of the above is: At the graduation ceremony of a South African university with a traditionally Christian character, a vast majority of (at least nominal) Christian students and a Christian theological faculty, the Christian theologian invited to do an opening prayer felt a Christian prayer should not be said because of fear of so-called coercion (the negative aspect of promoting and respecting). But it could also be argued that respecting the rights of the groups present meant it should have been said (albeit then in a non-coercive way that does not offend but shows respect to the different religious and non-religious traditions in the audience - the positive aspect of respect, protect, promote and fulfil).

In fact, a closer reading of the Constitution reveals that it does not only guarantee the free exercise of an individual's religion as a mere private affair, but that it also recognises the importance of the communal aspect of the free exercise thereof. It does so at least on two occasions: indirectly in Section 18 where it guarantees the right to "freedom of association" to everyone, and directly in Section 31(1) where the following is provided:

(1) Persons belonging to a cultural, religious or linguistic community may not be denied the right, with other members of that community -

(a) to enjoy their culture, practise their religion and use their language; and

(b) to form, join and maintain cultural, religious and linguistic associations and other organs of civil society.

\section{A secular-individualistic import}

My question is: Do we as South African religious groups and communities (note the emphasis!) recognise the challenge put to us by the Constitution to also find creative ways by which to celebrate our religious (and cultural and linguistic) diversity? Or do we always resort to the way of least resistance immediately, which is to opt for a dull non-conformity, justified by the secular-individualistic jargon that we so easily import from America and elsewhere?

Rather than a one-dimensional perception of what the state is, of what South Africa and we as its citizens are, we should remember that the state itself is nothing other than a "potpourri of its members' experience of religio-ideological justice and power" (Van Niekerk 1993:21). Precisely this rich variety of groups and cultures is the reason why the idea of a theocratic state on the one hand and a secular state on the other hand is intolerable (cf Van Niekerk 1993:21). Both are just too bleak a form to fully express the richness this potpourri of people encompasses. 
However, the way in which in South Africa religion and its relationship to the state is often defined, stems from what I call, a la Gedicks, a "secular-individualistic" hermeneutic framework. This framework results in a form of political secularism that demands that all religious discourse should be barred from the political and public sphere, or even influence the political discourse. It becomes the breeding ground for the type of remark that an advisor to the Minister of Education, Kadar Asmal, made in an interview on his role as the future management of religions in schools.

The advisor said that he envisaged voluntary religious assemblies at schools in the morning, even various assemblies for learners of various faiths. At the end of such assemblies, the bell goes and then the united hall assemblies follow where Saturday's rugby, for example, gets discussed (Die Burger 19.12.2001). In other words, the unifying role in schools of a culturally sectarian sport like rugby is elevated above any possible unifying role that religion could have (on the condition, however, that you like rugby so much that you do not feel yourself coerced into having to listen to the talk of those cultural groups that constitute the sport's heroes and admirers!).

When one considers the sometimes absurd results of the secular-individualistic hermeneutic framework as illustrated in the discussion so far, one cannot help but realise the aptness of Cavanaugh's observation that the founding myths of the modern secular state - in Hobbes, Rousseau and Locke - are all parodies of the Christian story. They describe human beings as individuals who must defend their (private) property against the encroachments of others. This myth can become effective only if it obliterates the Christian story of universal human communion. Because it cannot abide a "trans-national" church that might compete for the allegiance of citizens, it redefines religion as inward and private. The consequences of this redefinition continue to haunt us, both in our extreme individualism and in our reliance on violence (cf Cunningham 1999:1127).

\section{Secular-individualists at home}

An example par excellence of this secular-individualistic approach to the Constitution is to be found in the work of the South African professor of Law at UCT, Denise Meyerson (Reading the Constitution through the Lens of Philosophy 1997 and Rights limited. Freedom of expression, religion and the South African constitution 1997).

Meyerson is particularly interested in balancing Section 15(1) of the Constitution with Section 36(1), the so-called "Limitation Clause". This clause lays down the conditions under which a right protected by the Bill of Rights may permissibly be limited - which is to say overridden or infringed.

Meyerson makes it clear that the Constitution is a legal document that writes moral principles into law. "It is therefore a document which cannot be applied without recourse to moral reasoning" (1997a:1). Therefore, when any limitations on constitutionally guaranteed rights are discussed, it could only be done with a moral appeal, but then an appeal of a very specific kind: "The limitation clause does not test the legitimacy of restrictions on our constitutionally protected rights and freedoms by asking what all reasonable people would agree to from the perspective of their own interests. It binds us to much more, asking what all reasonable people would agree to from the perspective of everyone's inherent moral status, of their mattering equally" (1997b:14 - cursive by me). The decisive test for any limitation is: Does it do justice to human dignity, equality and freedom, to those values which characterise an open and democratic society - a reference which crops up again and again in the Constitution? 
Meyerson constantly emphasises the point: The basis for any justified limitation is that it should be accepted by all reasonable people - it should enjoy "common ground ... often described as neutral ground" (1997b:21). Therefore: "No limit on the right to religious freedom is permissible unless justified in terms of reasons which would carry at least some weight with all reasonable people" (Meyerson 1997b:21). This means that no collective or group interests (however strong they might be) may serve as a ground to limit a constitutional right. This, naturally, includes any religious grounds (Meyerson 1997:45). In any case, religious beliefs are "intractable disputed beliefs" - the name she gives to "reasons that cannot be offered in the public domain" and which cannot be criticised on the basis of common reason (1997a:6-7).

As South Africans, coming from a history where the sectarian interests of a specific cultural group trampled the rights, the human dignity, equality and freedom of other groups, one understands Meyerson's fear of group interests too well. But the nagging question remains: Is she not just trading group dignity for individual dignity, where the very definition of "individual" merely stems from another particular interest group's definition of individuality, namely that of the typical Western, capitalist, individualistic and secular democracy (albeit a very dominant group!)?

These fears are aroused even further when one reads that for her understanding of the concepts "equality and freedom", Meyerson uses John Locke's description, and for "dignity" Immanual Kant's. And indeed, these great philosophers are the founding fathers of much of the mythology of Western civilisation - but I am constantly haunted by Cavanaugh's observation above, that these mythologies are nothing more than parodies of the Christian story. Having heard about chauvinism, I cannot escape the question: Is the secular individualistic approach not just a different form of Western chauvinism? Tierney warns us against the danger of "... simply (to) inflate Western concepts into universal values and then assume without question that such values are valid for all other societies, regardless of their histories and cultures" (1996:43).

\section{Yes, religion can join the debate}

To conclude: In order for religion to have any moral impact on the public debate in South Africa, we should do away with a mere secular and individualistic understanding of the freedom that we as religious people have been granted under our Constitution. Failing to do this, would lead to a total privatisation of religion and a (religiously) naked public square. The constitutional text leaves ample scope for the protection of rights of religious groups.

Surely, the formulation of Section 15(1) on its own is indeed very minimalistic and individualistic. However, when one reads all the relevant Sections of the Constitution in relation to one another, also the rights of religious groups are guaranteed by the Constitution (cf Du Plessis 2001: 8-14). This gives us another angle by which to look at matters like school prayer, and other issues affecting the public morality of South Africans.

Politically, concepts like groups, ethnicity and class have become suspect. Therefore the secular-individualistic approach is the politically more correct and safe one. Despite that, I agree with Villa-Vicencio who says religion, language, ethnicity, class identity and gender are important aspects of human identity. In as far liberalism underestimates these issues, "... it ignores an essential dimension of what it means to be fully human" (1996:519).

I have already referred to the link often drawn between religious freedom and democracy above. Therefore, another of Villa-Vicencio's remarks about democracy is very relevant: "Democracy is about the proliferation of stories, symbols, languages, and religions. The exclusion of these is tantamount to the exclusion of people whose identity is 
constituted by them" (1996:530). This, indeed, is the problem with the secularindividualism by which many American courts in recent years have interpreted their Constitution, and the model that seems to rule in the popular South African mind.

Martin Marty hits the nail on the head when he alleges that the belief that you can deal with the interests of people from a so-called "neutral point" somewhere above the religious sphere, for example a typical Aufklärung understanding of democracy, "... is to show unawareness that the religions of the world regard Enlightenment reasoners to be one more set of competitors on the religious scene" (1965:15).

Because of their intense awareness of the impoverished hermeneutic results created by the secular-individualistic discourse, both the above mentioned academics choose for an approach / discourse that does more justice to the potpourri of democracy.

Whatever this alternative to secular-individualism may be called (religious communitarian?), to both of them "tolerance" (Marty) and "cultural openness" (Villa-Vicencio) are the most fundamental characteristics thereof. Tolerance and cultural openness are not passive concepts, but very active ones: “... ultimately the negation of a negation, a counterintolerance” (Marty 1996:13); “... rising to a higher universality that overcomes not only our own particularity but also that of the other. ... that one learns to look beyond what is close at hand - not in order to look away from it but to see it better, within a larger whole and in truer proportion" (Villa-Vicencio, referring to Gadamer 1994:305).

Does the Constitution preserve the right for us as religious people to contribute to the public debate on morality? Indeed - as long as we realise that the Constitution allows us to do it on a collective and group basis. This is not an inferior, less reliable approach than that of secular-individualistic rationalism that, since the Aufklärung, has enjoyed such a field time among Western academics.

"Not indifference to religion or the incomprehensibility of the other, but reflective difference, based on the always ambiguous and problematic but resource-rich religious traditions, can become an instrument for enlarging and assuring human rights. To neglect such a possibility in our religiously crowding and jostling world would seem to be a misreading of the signs of the times and a neglect of potentially positive resources", are Martin Marty's wise words to be remembered (Marty 1996:16).

\section{BIBLIOGRAPHY}

Ackermann, LWH 2001. Some reflections on the constitutional court's freedom of religion jurisprudence. Unpublished lecture, Church/State Conference. Stellenbosch: October 2001.

Abraham, HJ 1995. Constitutional and other definitions of religion: the contemporary scene. In: Lee, FG. (ed.): All imaginable liberty. The religious liberty clauses of the First Amendment. Lanham: University Press of America, 167 -191.

Cunningham, DS 1999. Review on The New Orthodoxy? (J Milbank et al) in: Christian Century Nov 17-24, 1127-1129.

Chaskalson, Metal 1998. Constitutional law of South Africa: application. Cape Town: Juta (page 10-26 to 10-29).

Dolan, J 1995. From coercion to persuasion: the rise of religious freedom. In: Lee, FG (ed.): All imaginable liberty. The religious liberty clauses of the First Amendment. Lanham: University Press of America. 
Du Plessis, L 2001. Current problems concerning church and state relationships and religious freedom in South Africa. The viewpoint of a constitutional lawyer. Unpublished lecture, Church/State Conference. Stellenbosch: October 2001.

Durand, JJF 2002. Ontluisterde Wêreld. Wellington: Lux Verbi BM.

Eastland, T(ed.). 1993. Religious liberty in the supreme court. The cases that define the debate over church and state. Grand Rapids: Eerdmans.

Gadamer, H-G 1994.Truth and method. Continuum: New York ( $1^{\text {st }}$ English translation: 1975. Original: 1960 in German).

Gamwell, FI 1995. The meaning of religious freedom. Modern politics and the democratic resolution. New York: State University of New York Press.

Gedicks, FM 1995. The rhetoric of church and state. Durham: Duke University Press.

Koshy, N 1992. Religious freedom in a changing world. Geneva: WCC Publications.

Marty, M 1996. Religious dimensions of human rights. In: Witte, J \& Van der Vyver, JD (eds.): Religious human rights in global perspectives. The Hauge: Martinus Nijhoff.

McConnell, MW 1993. Taking religious freedom seriously. In: Eastland, T (ed.): Religious liberty in the supreme court. Grand Rapids: WB Eerdmans.

Meyerson, D 1997a. Reading the Constitution through the Lens of Philosophy. Cape Town: Dept of Communication, UCT.

Meyerson, D 1997b. Rights limited. Freedom of expression, religion and the South African constitution. Cape Town: Juta.

Lawrence, R; Gordon, $R$ \& Solberg, NMP vs The State 1997. Constitutional Court of South Africa (cases CCT 38/96, CCT 39/96 and CCT 40/96).

Saayman, WA 1993. Religious freedom in apartheid South Africa. In: Kilian, J (ed.): Religious freedom in South Africa. A collection of papers presented at the seventeenth symposium of the Institute for Theological Research (Unisa) held at the University of South Africa in University of South Africa. Pretoria: Unisa, Institute for Theological Research Symposium.

Sachs, A. 1990. Protecting human rights in a new South Africa. Cape Town: Oxford University Press.

Smith, N 1998. Freedom of Religion. Revision Service 2 (page 19-1 to 9-14).

Tierney, B 1996. Religious rights: an historical perspective. In: Witte, J \& Van der Vyver, JD (eds.): Religious human rights in global perspectives. The Hague: Martinus Nijhoff.

Van Niekerk, E 1993. What is religious freedom? In: Kilian, J (ed.): Religious freedom in South Africa. A collection of papers presented at the seventeenth symposium of the Institute for Theological Research (Unisa) held at the University of South Africa in University of South Africa. Pretoria: Unisa, Institute for Theological Research Symposium.

Villa-Vicencio, C 1996. Identity, difference and belonging: religious and cultural rights. In: Witte, J \& Van der Vyver, JD (eds.): Religious human rights in global perspectives. The Hague: Martinus Nijhoff.

Witte, J 1996. Introduction. In: Witte, J \& Van der Vyver, JD (eds.): Religious human rights in global perspectives. The Hague: Martinus Nijhoff.

\section{Newspapers}

Die Burger 19.12.2001

Washington Evening Star 27.06 1962; 18.06.1963

Wall Street Journal 27.06.1962 